\title{
LANDSLIDE RISK MANAGEMENT IN THE URBAN DEVELOPMENT OF SANDNES (NORWAY)
}

\author{
Diego López Mulero ${ }^{1}$, Ove Njå ${ }^{1}$, Carlos López Fernández² \\ ${ }^{1}$ Department of Industrial Economics, Risk Management and Planning, University of Stavanger, \\ Stavanger, Norway; diego.lopez.mulero@sandnes.kommune.no; ove.njaa@uis.no \\ 2 Department of Geology, University of Oviedo, Oviedo, Spain; lopezcarlos@uniovi.es
}

KEY WORDS: Landslide, Climate Change, Geotechnical, Land-use

\begin{abstract}
:
The research reported focuses on the multi-causal landslide risk in Sandnes (Norway) in connection with the climate change, the use of the land and the geological/geotechnical properties of the urban subsoil. The municipality is giving special focus on the potential climate change challenges in the development plans of the city and the weather is a significant triggering factor of landslides. The average annual precipitation is $1290 \mathrm{~mm}$ and the Norwegian Environmental Agency (NEA) estimates a $10 \%$ increase by 2100 and a $40 \%$ increase for the short-term rainfall (3h). In addition, the NEA expects sea level to rise between 59 and 89 . The study includes records of land use, demographic growth $(+1.5 \%$ annually), historical maps and aerial imagery. Events occurred in the past have been inventoried by interviews and document retrieval. Additionally, geological, geotechnical and hydrogeological data from surveys performed in the area have been gathered. The data material is georeferenced in a GIS database for visualization and further treatment. We give special attention to the quality and density of the data to account for the uncertainty and lack of information for certain subareas within the geographical boundaries. This will provide guidance for future work such as soil sampling campaigns. A multilayered model has been created combining the different aspects studied: elevation, slope, hydrology, historical information and geological data. We model the urban area theoretically affected by the sea level rise and the potential effects on different soils. Finally, the work includes preliminary landslide hazard and vulnerability maps of the present urban plot.
\end{abstract}

\section{INTRODUCTION}

The consequences of climate change on urban environments poses great difficulties for decision makers and politicians. Some consequences are currently observable while others are associated with uncertainties. Sound assessments results are often challenging for the scientific community and the effects of the climate change on hydro-geological hazards (e.g. landslides, floods) are still difficult to resolve and forecast. Therefore, it is not surprising that administrations, such as the municipality of Sandnes (Norway) are taking actions to increase their knowledge and mitigate the effects of the existing hazards and their potential escalation due to climatic changes.

\subsection{Landslide Risk}

Landslides represent one of the world's major natural hazards. Precipitation and temperature changes are some of the most significant causes of slope instability directly affected by the climate change (Dhakal and Sidle, 2004; Sidle and Ochiai, 2006; Crozier, 2010). In addition, human actions, such as land use and geological and geotechnical conditions of the subsoil must be considered for an appropriate assessment. Frequently, there is extensive information and studies about land use and geology. However, knowledge is limited on the subject of the effects of climate and its variation on landslide hazards and their related risks (McInnes et al., 2007; Crozier, 2010; Dijkstra and Dixon, 2010; Coe and Godt, 2012).

Due to Norway's geological history and resulting landscape, landslides are among the natural hazards that causes most loss of life and economic loss. Since the 1940s, landslides of different nature have killed over 50 people (Furseth A., 2006). Rock falls, debris flows and lateral spreads (quick clay) are among the most common types. Some well-known examples are listed below:

- Verdal, 1893: is the largest and most severe known quick clay slide in Norway. 55 million $\mathrm{m}^{3}$ slid out and 116 people were killed.

- Loen, 1905 and 1936: two rock avalanches occurred within 30 years in the same location. The first one killed 61 people and c. $50000 \mathrm{~m}^{3}$ slid out and the second one killed 76 .

- Tafjord, 1934: rock avalanche that killed 40 people.

- Rissa, 1978: is the largest quick clay slide in Norway in the $20^{\text {th }}$ century. 5-6 million $\mathrm{m}^{3}$ clay slid out and 1 person was killed.

- Kattmarka, 2009: clay slide in connection to road works in mid-Norway. No casualties.

- Sørum, 2016: biggest recent quick clay slide. Its dimensions were 400 by $300 \mathrm{~m}$ and 3 persons were killed.

Most of the cases are landslides linked to rainfall events and/or human activity (e.g. buildings, earthworks, road works). Sandnes municipality wish to be in forefront in their societal safety work, specially linked to climate change. They are working towards this goal by supporting studies and taking actions against the effects of the climate change, in cooperation with other municipalities and institutions.

Landslide risk management implies knowledge and modelling skills in geosciences (geology, hydrology, geotechnics), civil engineering and critical infrastructure, urban planning, economics and social sciences. However, regardless of the approach, applied geographical information systems have been a powerful instrument to conduct landslide risk studies. 


\subsection{The case of Sandnes Municipality}

Sandnes is a city and municipality in Rogaland County located in the Southwestern part of Norway. It was originally best known for its brick and pottery industry. Clay has been extracted from the slopes around the old settlement for nearly 100 years. These slopes have been integrated into the city due to the urbanization process and they are among the most precarious areas in terms of ground stability.

Sandnes is located around the southern part of the Gandsfjord, (Figure 1). The harbour, the area surrounding the fjord (especially to the West) and the river valley towards the South, comprise the main populated area, while the municipality has its largest area on the eastern side. Topographically, the Gandsfjord and Ganddal form a boundary between the plain landscape of Low-Jæren in the West and the hilly landscape of the Høgsfjord and High-Jæren in the East.

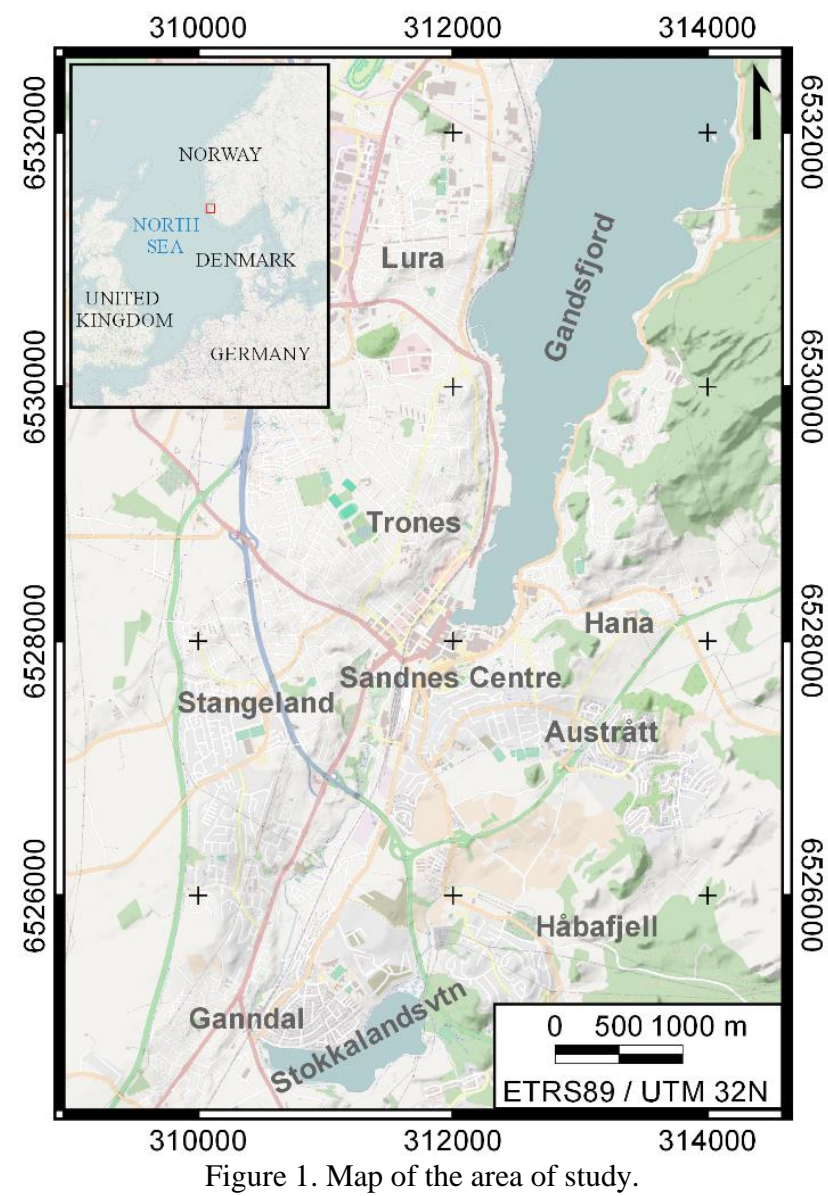

The municipality of Sandnes, with its 76.169 inhabitants as per the $3^{\text {rd }}$ quarter of 2017 is Norway's seventh largest city and eighth largest municipality. It is considered part of the Stavanger region, with a total of 336.083 inhabitants.

\subsection{Major Issues}

In this paper, we analyse existing knowledge of soils conditions in the city centre of Sandnes to address future challenges regarding city development, climate change predictions, uncertainties and risk management where landslides are a part of the societal safety concerns. The study addresses the sea level rise (SLR) and the landslide susceptibility challenges from a qualitative perspective using climatic data, geomorphologic data, demographic information, historical records, hydrogeological data, landslide inventories, aerial photographs and satellite imagery.

The research, sponsored by the municipality of Sandnes, is considered pioneering research in Norway at the municipal level. The outcome will be input to the strategic city planning creating sound evidence based landslide and sea level rise models. It will increase the local knowledge to a detailed scale for a more resilient society model in the municipality generating experience of processes and issues with opportunity for transferability.

\section{METHODOLOGY}

\subsection{Overview of challenges, tasks and analyses}

This work starts from an exhaustive data gathering, mostly belonging to the Public Administration and is an ongoing process nowadays. Entering the municipal administration with an assumption that all data material needed is in place and adapted to a format easy to integrate into analyses, is flawed. Norwegian municipalities and local governments are autonomous and responsible for a large number of services, including area development and societal safety. Collecting and retrieving data in municipal administrations is a complex task, because archives are not perfect, studies involving soil assessments are fragmented and distributed over several departments. In addition, gathering data needs identification of experts and previous employees who have worked with the issue of landslides. Finally, considerable knowledge and data is located outside the municipality, for example with consultancies.

From the collected data, we have carried out an expected sea level rise estimation and a preliminary landslide susceptibility map, following the structure described in Figure 2. The sea level rise has been modelled using climatic and topographic data (aerial imagery, current sea level, coastal boundaries and a digital terrain model of the municipality with a $0.25 \mathrm{~m}$ grid size). Information about sea level is based on the Norwegian vertical reference system (NN2000) and it was converted to match the utilized datum. The landslide susceptibility map is based on demographic data, historical data, soil conditions, hydrological information. The slope model used for the map has been created from a digital terrain model of $10 \mathrm{~m}$ grid size.

The data was gathered, implemented and processed with QGIS software (version 2.18.16) and various plugins from GDAL/OGR, Grass GIS and SAGA. The coordinate reference system used was ETRS89 / UTM Zone 32N, being the most commonly used in the region.

We also address major uncertainties in the data material and provide input to the need for further data gathering in order to develop landslide models and improve validity and reliability in societal safety considerations. 


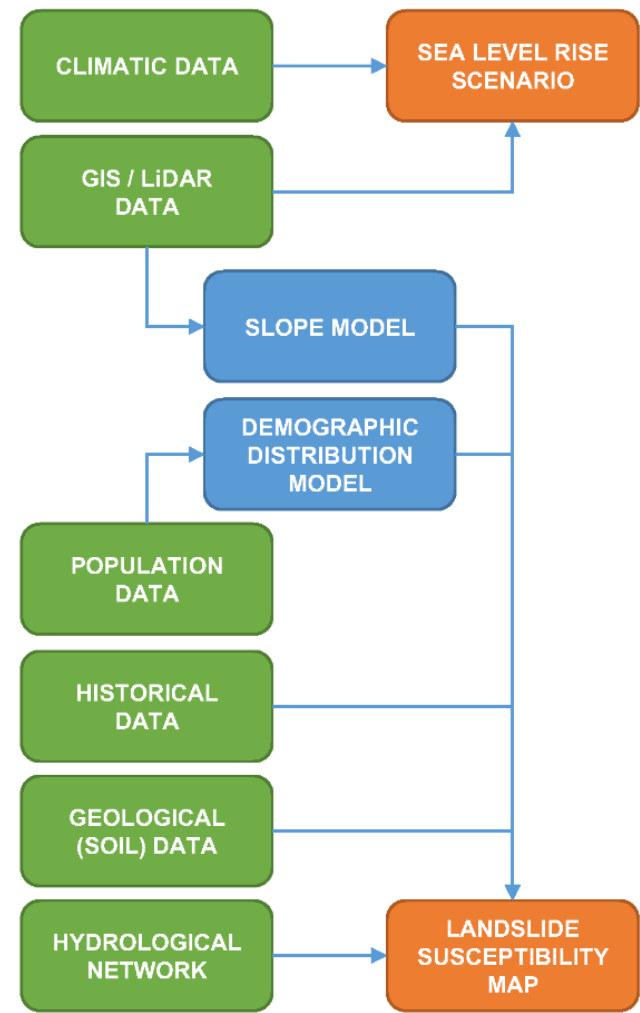

Figure 2. Schematic workflow diagram of the sea level rise and landslide susceptibility analyses.

\subsection{Demographics in Sandnes}

The population of Sandnes has grown since the 1960s with the peak of growth in the past 10 years. The local administration expects that the current growth rate will be maintained during the next two decades (Figure 3).

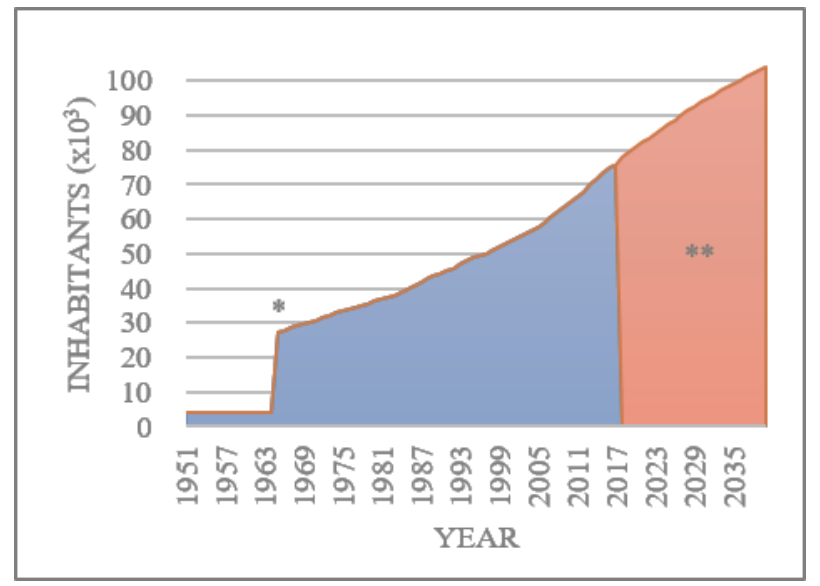

* In 1965, the municipalities of Høyland and Sandnes merged into Sandnes Municipality

** Expected

Figure 3. Population development of Sandnes for the period between 1951-2040. Data: Statistics Norway.

Typically, people in this region lives in single-family detached houses. However, the growth is changing the panorama regarding type of housing and the number of blocks of flats increase faster than other types of buildings, for example, detached or semidetached houses (Figure 4).

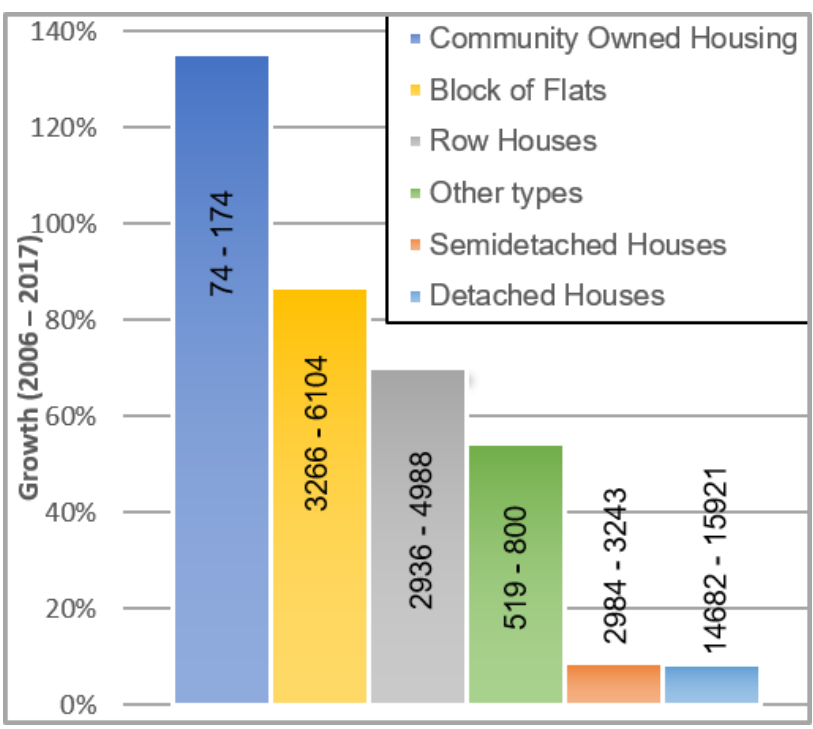

Figure 4. Development of Sandnes during the period 2006-2017 by type of building. Columns show the growth in percentage and numbers indicate the absolute values of buildings by type. Data: Statistics Norway.

We find that the constructions being built in the municipality are heavier than what was previously the norm. Hence, it is essential to provide a better understanding of the soil geotechnical parameters for slope stability or foundation design.

\subsection{Geological setting}

In geological terms, Sandnes is located on the border of two orogenic systems. The Sveconorwegian orogeny, to the East, consists of two main geological formations of Proterozoic rocks. A base of 1600 - 1450 million years old slates, quartzites, marbles and amphibolites, overlaid by large formations of granite dominating the upper structures. To the West, the municipality belongs to the lower and middle slopes of the Caledonian orogeny, which starts here and extends northward. The lower part of the orogen consists of shale and phyllites, while the middle, found along the coast, consists of granite and augen gneiss from the mid-upper Proterozoic (Ramberg et al., 2007).

Slope stability and therefore, landslide risk in the area of study, is mainly linked to soil conditions rather than rock formations. The different sediments that are found in the municipality based upon their genesis are (Figure 5):

- Glaciofluvial deposits: consist of sorted, often inclined layers of different grain size from fine sand to stone and block. They often have clear surface shapes like terraces. The thickness is often several tens of meters.

- Fluvial deposits: materials transported and deposited by rivers and streams. Typical shapes are floodplains. Sand and gravel dominate and the material is sorted and rounded. The power ranges from 0.5 to more than $10 \mathrm{~m}$.

- Anthropogenic materials: soils fed or strongly influenced by human activity, primarily in urban areas. The thickness of these materials diverges significantly in the area, reaching depths greater than $10 \mathrm{~m}$. 
- Lacustrine deposits: materials deposited in lakes where the thickness is more than $0.5 \mathrm{~m}$.

- Beach deposits: beach washed sediments formed by wave activity in freshwater. The materials are often rounded and well sorted. Grain size varies, but sand and gravel are the most common. The thickness of this unit is around $0.5 \mathrm{~m}$.

- Moraine materials: collected, transported and deposited by glaciers, usually hard packed, poorly sorted and can contain anything from clay to stone and block. Thick moraine deposits include sediments from $0.5 \mathrm{~m}$ to several tens of meters whereas thin moraine comprises the thickness below $0.5 \mathrm{~m}$.

- Peat: organic soil with a thickness greater than $0.5 \mathrm{~m}$.

- Bedrock: areas with lack of soils. More than $50 \%$ of the area consists of rock outcrops in the present time.

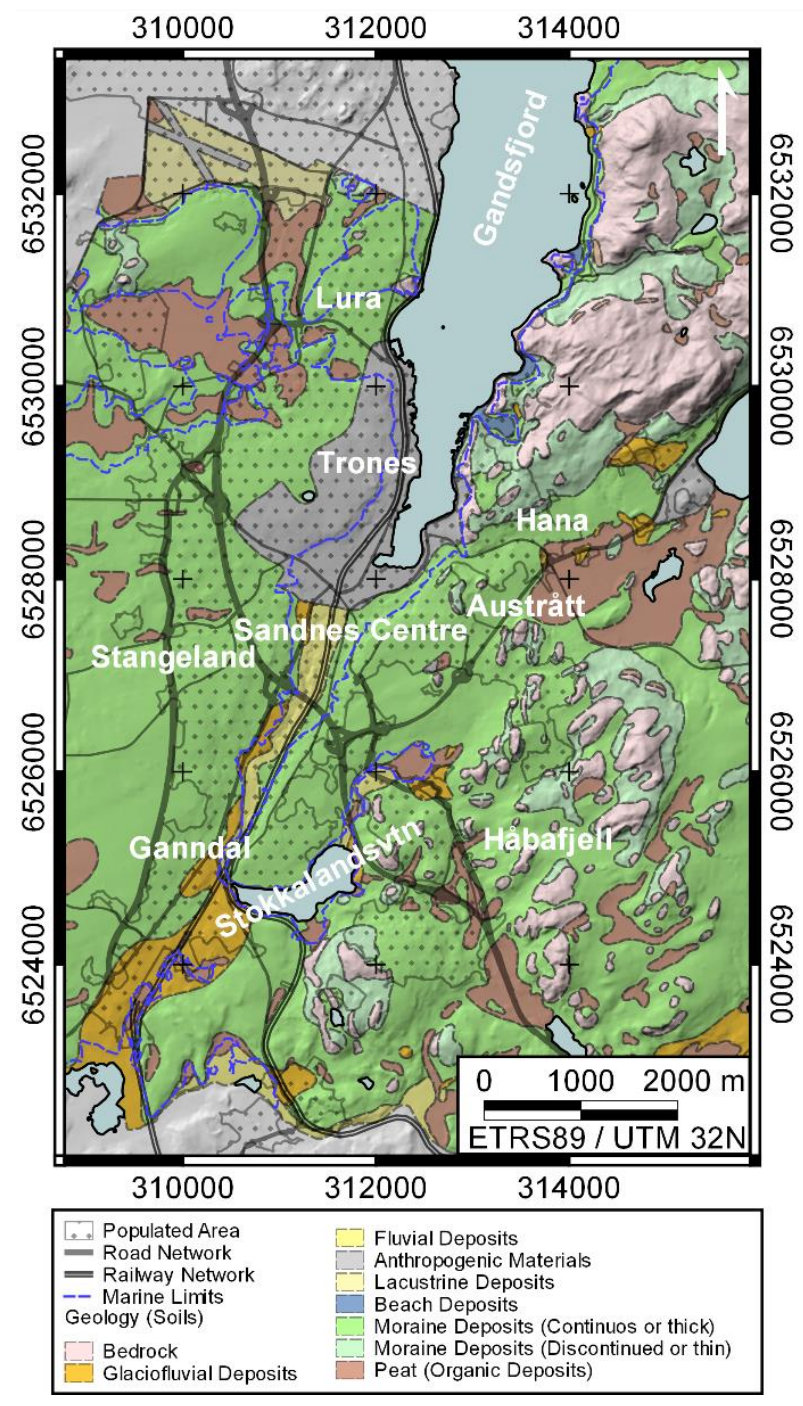

Figure 5. Map of soils of Sandnes.

The geological and geotechnical properties differ significantly across the terrain and in depth, as the soils have very different genesis. They are heterogeneous even within one soil type.

\subsection{Historical data gathering}

In Sandnes, numerous landslides have taken place in recent history. According to Norwegian Water Resources and Energy Ministry database, the sloping areas containing clay soils (Figure
5) are the most frequent to slide and the largest documented landslides took place in the western slope of the city, in the neighbourhood of Trones, in the area of one of the main old clay pits:

- $17^{\text {th }}$ December 1956. This landslide involved a volume of $680000 \mathrm{~m}^{3}$ reaching a maximum deformation of $30 \mathrm{~cm}$, so this was more like a displacement and not a landslide in the ordinary sense.

- $12^{\text {th }}$ August 1963. This slide moved $500000 \mathrm{~m}^{3}$ of material across an area of c. 30 ha after an extreme rainfall event. Large clay masses began to move and cracked in the streets of the Gann (Trones). A contributing factor was the excavation of a slope in the northern part of Langgard. Dozens of houses in the area had cracks. 40 houses were evacuated, but they could move back after a few days.

The study of this area with major landslides, which are built over clay pits and considered the most susceptible based on historical events, is one of the facts that has driven the realization of this research. However, it is equally important to improve this knowledge to the rest of the municipality where similar soil conditions are found, since the city is developing quickly.

\subsection{Climate framework}

Sandnes has a typical Atlantic climate with high precipitation throughout the whole year. It is open and very exposed to the storms from the North Sea. Winter is mild and sleety, and summer temperatures are above the national average. The winter temperature is seldom lower than $-4^{\circ} \mathrm{C}$, and in the summer, it is rarely above $24^{\circ} \mathrm{C}$.

The coastal climate in the region is warmer than the geographical conditions would normally indicate, due to the Gulf Stream. This gives the city a warm climate, despite the fact that Sandnes is just below the same latitude as the southern tip of Greenland. Figure 6 shows the annual normal temperatures and rainfall for the weather station that is nearest to Sandnes.

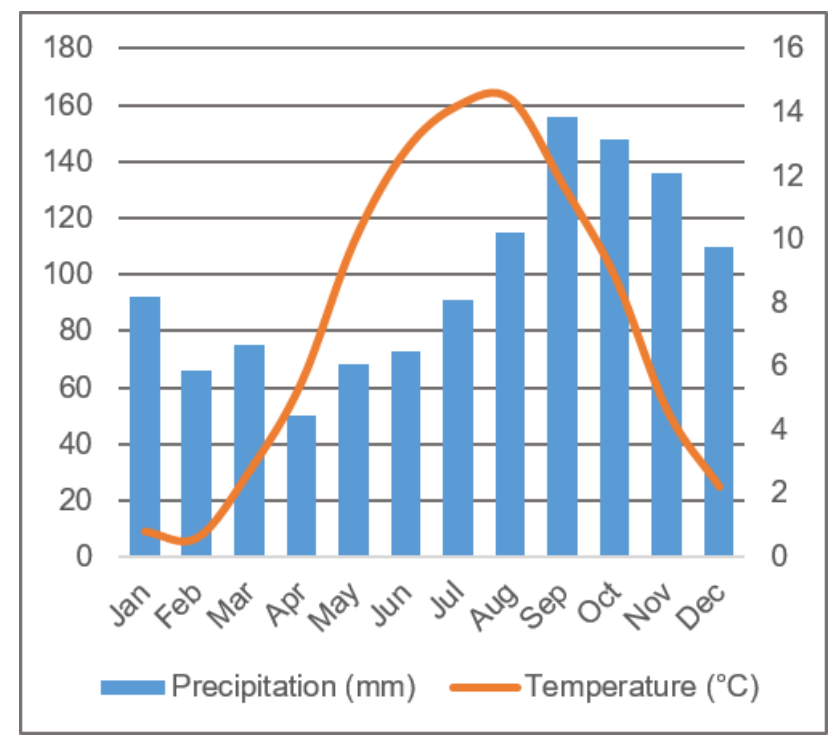

Figure 6. Average precipitation and temperature at Sola weather station (located $7 \mathrm{~km}$ from Sandnes) by month, for the normal period 1961 to 1990 .

Global warming causes melting of land ice and thermal expansion making the oceans to absorb a significant extra heat 
expanding the water volume, and thus rising sea levels. Sandnes municipality adopts recommendations from Simpson et. al. (2015), Representative Concentration Pathways (RCP) 8.5 in their urban planning and development work.

Climate change consequences on the climatic conditions for Sandnes are noticeable at the present time, There is increased precipitation, both in terms of number of days, and total amount. Moreover, the temperature is expected to increase c. $3.5^{\circ} \mathrm{C}$ and the yearly precipitation c. $10 \%$ during the $21^{\text {st }}$ century with the greatest increase in the winter.

Both mean sea level (MSL) and sea level extremes (SLE) (e.g. storm surge) will intensify in Sandnes. Storm surges occur when a low-pressure weather system and increased surface wind stress simultaneously contribute to increased sea levels and push water up against a coast. In this process, the strength of the storm, its track and speed, as well as geographic features of the coastline and bottom relief, act in concert. Storm surges contribute to a water level that is considerably higher than the astronomical tide, but whether or not the resulting water level is substantial also depends on the tidal regime. In the Sandnes region, the weather effect dominates the astronomical tide. Here storm surges can have consequences regardless of the tides. The expected mean sea level increments are presented in Table 1.

\begin{tabular}{|c|c|c|c|}
\hline \multirow{2}{*}{ RCP } & \multicolumn{3}{|c|}{ Sea level change $(\mathrm{cm})$} \\
\cline { 2 - 4 } & Mean & $5 \%$ & $95 \%$ \\
\hline 2.6 & 29.0 & 4.0 & 54.0 \\
\hline 4.5 & 38.0 & 12.0 & 63.0 \\
\hline 8.5 & 59.0 & 28.0 & 89.0 \\
\hline
\end{tabular}

Table 1. Projected sea level change and 5 to $95 \%$ ensemble spread for different RCP by year 2100 .

Table 2 presents the storm surge return heights estimated for the periods of 20, 200 and 1000 years. The selected height for the analysis is $129 \mathrm{~cm}$, corresponding to the percentile $95 \%$ of the return height for 1000 years.

\begin{tabular}{|c|c|c|}
\hline $\begin{array}{c}20 \text { year return } \\
\text { height }(\mathrm{cm})\end{array}$ & $\begin{array}{c}200 \text { year return } \\
\text { height }(\mathrm{cm})\end{array}$ & $\begin{array}{c}1000 \text { year return } \\
\text { height }(\mathrm{cm})\end{array}$ \\
\hline $101(95,104)$ & $115(106,119)$ & $123(113,129)$ \\
\hline
\end{tabular}

Table 2. Return heights in centimetres above mean sea level

(1996-2014 period), with confidence intervals in parentheses.

Table 3 shows the estimated number of years until 2100 that the return heights will be reached for various RCP.

\begin{tabular}{|c|c|c|c|c|}
\hline 2001-2100 & $\begin{array}{c}\text { No RSL } \\
\text { change }\end{array}$ & RCP2.6 & RCP4.5 & RCP8.5 \\
\hline 20-year & 5.0 & 56.1 & 57.3 & 62.4 \\
\hline 200-year & 0.5 & 11.1 & 22.2 & 38.1 \\
\hline 1000-year & 0.1 & 3.2 & 6.5 & 25.8 \\
\hline
\end{tabular}

Table 3. Expected number of years that the present-day return heights are exceeded for the period 2001-2100.

The Glacial Isostatic Adjustment (GIA) is another factor influencing the sea level change in the region. This movement, which is $1.3 \mathrm{~mm} /$ year (upwards) Simpson et al. (2015), is not considered in the calculations of this study.

\section{RESULTS}

\subsection{Sea level rise}

The sea level rise for the municipality of Sandnes is calculated using the RCP 8.5 worst case scenario (Simpson, et al. 2015):

- Mean sea level rise: $89 \mathrm{~cm}$, corresponding to the $95 \%$ percentile for the RCP 8.5.

- Storm surge sea level rise: $129 \mathrm{~cm}$; corresponding to the $95 \%$ percentile for the 1000 year return height. As Table 3 shows, the current return heights (presented in Table 2) will be exceeded a number of times, and therefore invalidated, until 2100. An exceedance of 25.8 years is estimated for the 1000 year return height for the RCP 8.5.

- The Norwegian vertical reference system (NN2000) is $+9 \mathrm{~cm}$ and it was converted to match the utilized datum.

Total SLR $=$ mean SLR + Storm surge SLR - Datum adjustment

Total SLR $=89+129-9=209 \mathrm{~cm}$

The current harbour is designed to contain a 200 years return height $(115 \mathrm{~cm})$ storm surge, thus, the current walls will control the mean sea level change in itself. However, considering the 1000 year return height in combination with the mean sea level rise, a relatively large area of the city centre will be flooded by the sea (Figure 7). The affected area (c. 70 ha) includes the harbour facilities and businesses, the future city council building and several public buildings (e.g. public library, schools and kindergartens, unemployment service building, the culture school), several shopping centres, the bus station, the train station access, the main pedestrian street, two gas stations and many blocks of flats and houses.

\subsection{Landslide susceptibility}

The landslide proneness of an area is linked to several factors. In this study, we have considered the following:

- Land use: associated to types of buildings. The design premises adopt the areas with higher population density as the most susceptible for landslides.

- Terrain slope: the angle of the terrain will influence the occurrence of landslides. The greater the incline, the more susceptible the area will be to slide.

- Geology: susceptibility to slides will also depend on the properties of the subsoils.

- Historical data: the slides occurred in the past as well as human actions in the terrain such as clay pits or any other modification of the terrain. Figure 9 shows the locations of the old clay pits.

\section{Land Use}

The model of the demographic distribution presented (Figure 8) shows the population density in the urban area of Sandnes. The areas with higher density correspond to the neighbourhoods with blocks of flats or community owned buildings. For the purpose of this study, the susceptibility to landslides, the demography is linked to the type of construction and infrastructure that is developed for a particular area, however, this is a fact to consider for the vulnerability analysis and it will be part of future work within the research. 

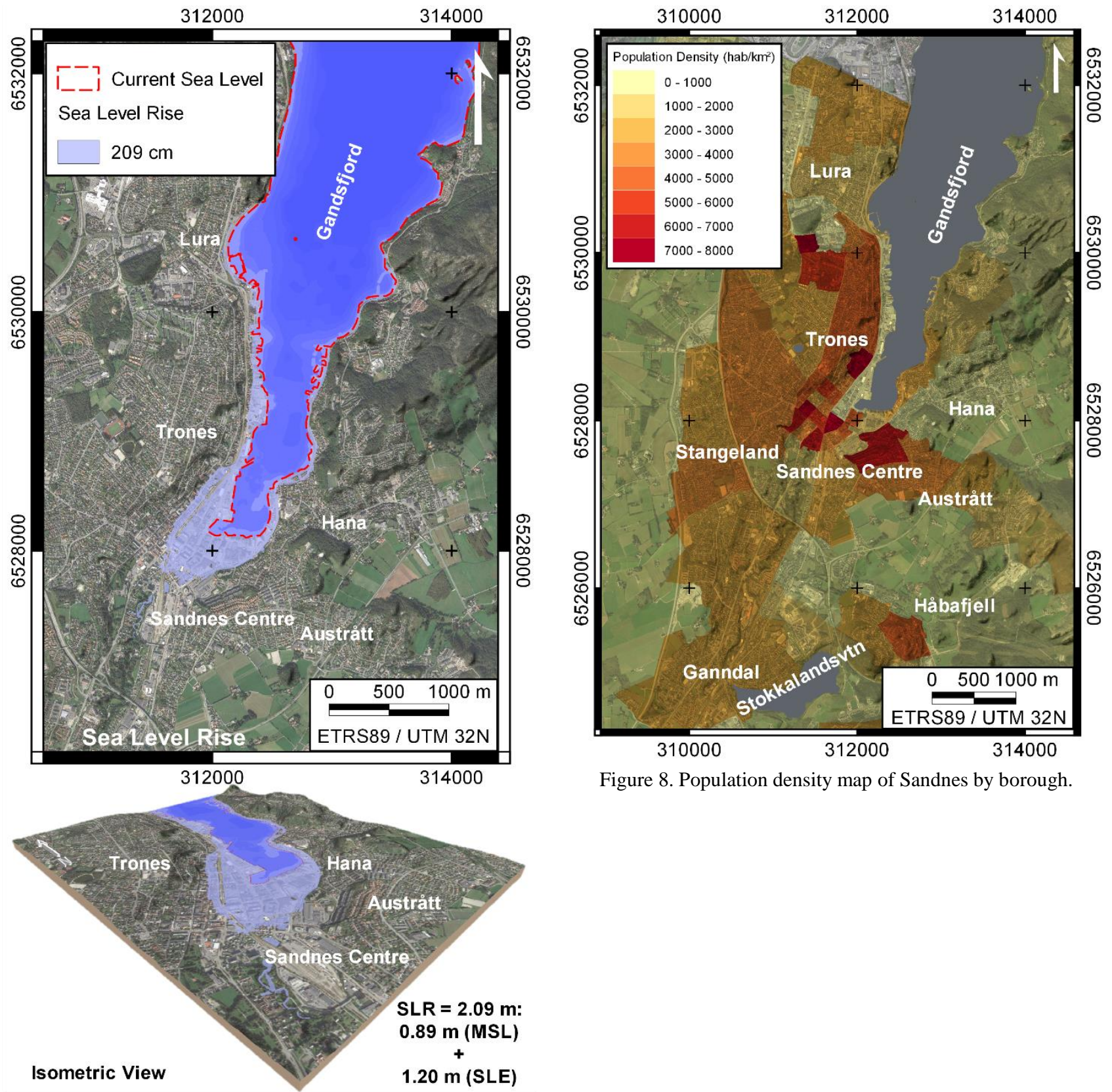

Figure 8. Population density map of Sandnes by borough.

Figure 7. Expected sea level rise in storm surge conditions by year 2100.

\section{Slope mapping}

The slope map is built from a $10 \mathrm{~m}$ grid size digital terrain model. Various digital terrain models were tried $(0.25 \mathrm{~m}, 0.5 \mathrm{~m}, 1 \mathrm{~m}$, $5 \mathrm{~m}$ and $10 \mathrm{~m}$ grid size) and the $10 \mathrm{~m}$ grid was considered the best approach for the selected work scale.

The slope map (Figure 9) highlights the areas with higher terrain angle. Most of them are linked to rock outcrops, specially to the East and Southeast, but other slopes are present in soils. These slopes are correlated with human activities (such as old clay pits). Moreover, the marine limits have a clear alignment with steep terrain in soils, revealing the ancient steep continental shelf. 


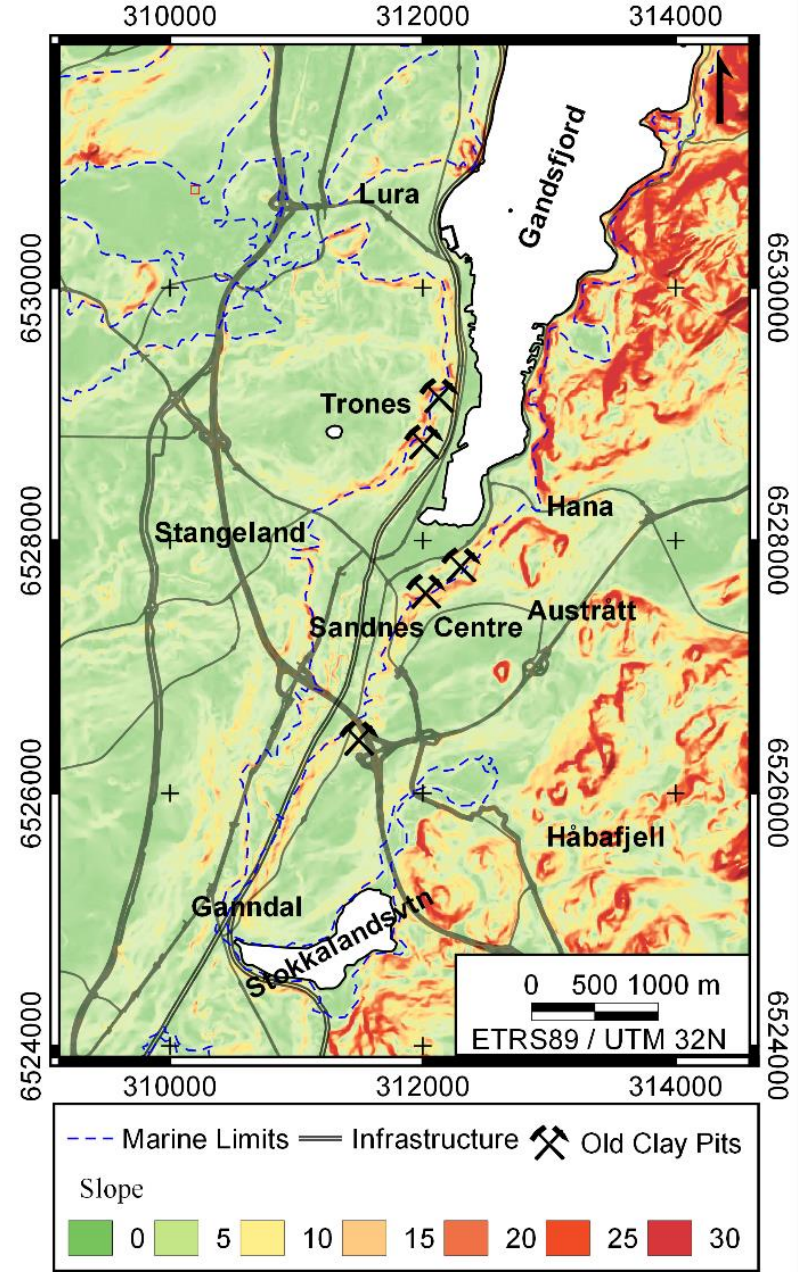

Figure 9. Slope map.

\section{Susceptibility cartography}

The susceptibility map (Figure 10) was developed combining the data regarding the above listed factors: land use, terrain slope, geology (soils), and historical data. The map is arranged in six degrees of susceptibility (from zero to high). The areas with higher values are located in the Northeastern part. These correspond to unpopulated mountain areas of high slopes where the rock outcrops appear.

Towards the Southeast there are areas of high or medium-high susceptibility, in the neighbourhood of Hana, linked to slopes in thin moraine deposits. In the centre of the city, the areas with the highes susceptibility are related to the old clay pits and surrounding zones. Here, the thick moraine sediments (typically with high clay content) are present.

The remaining area consist of low to zero susceptibility degree. These are related to moraine sediments in relatively flat areas (for the low susceptibility) and glaciofluvial and fluvial deposits (for the very low to zero values).

There is uncertainty regarding the anthropogenic deposits, as they area covering other soils with very variable thickness. Towards the South, the rock outcrops coexist with thin moraine sediments in high slope areas. Analogically to Hana, the highest susceptibility corresponds to thin moraine near by the outcrops.

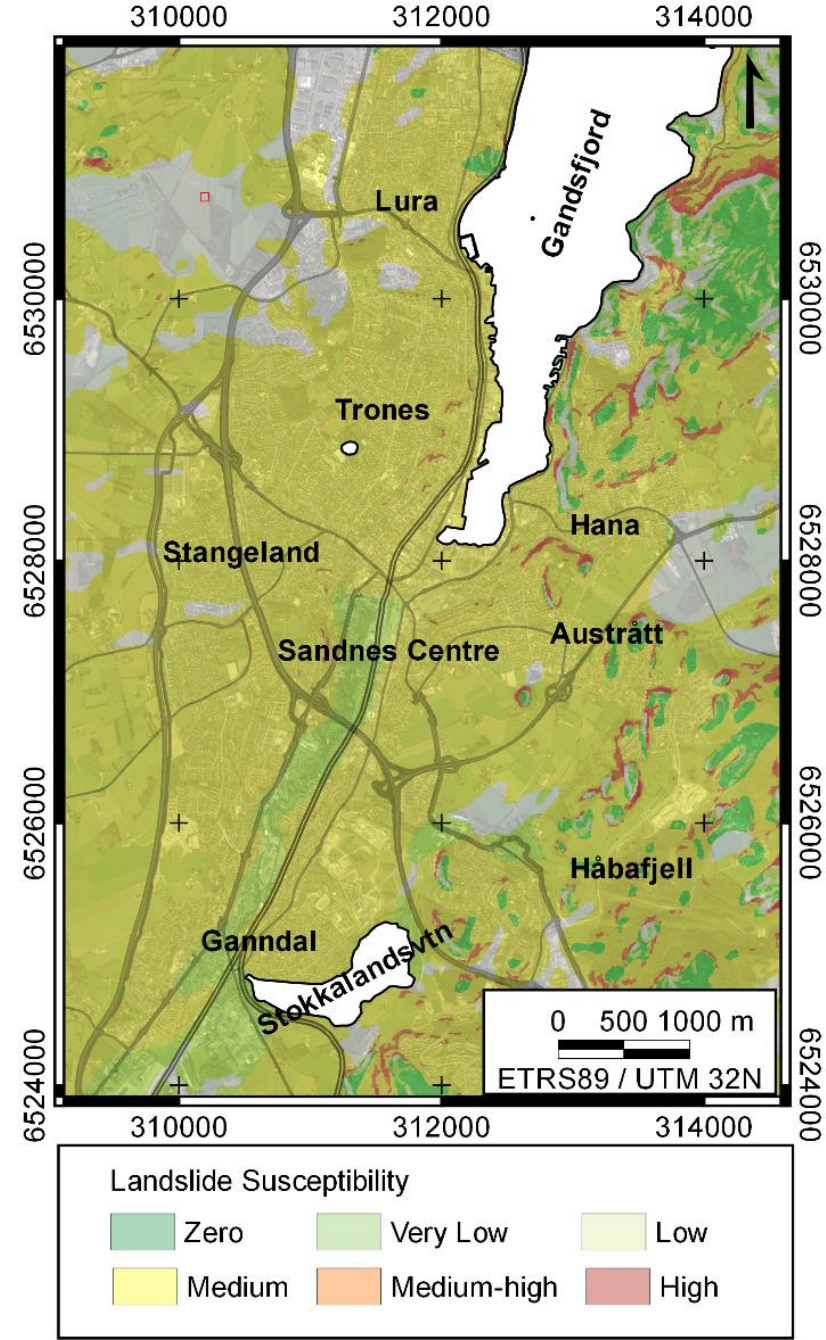

Figure 10. Landslide susceptibility map of Sandnes.

\section{DISCUSSION AND CONCLUSIONS}

\subsection{Sea level rise}

Changes to mean sea level and sea level extremes (e.g., storm surges) will lead to changes in coastal impacts. This represents a changing exposure and risk to the society. As a major contribution of this research work, with regards to the sea level rise, we have identified the floodable area for Sandnes in the event of a storm surge for a 1000 years return period. The sea level rise is expected to be $209 \mathrm{~cm}$ and it would imply a flooded area of 70 ha. The city centre is the most seriously affected zone in terms both extent and the seriousness of consequences.

These conclusions are not in agreement with the current municipal planning policy to ensure that the lowest floor level (ground floor) in new buildings is at least $+2.00 \mathrm{~m}$ above datum. In addition numerous older buildings and infrastructure, such as low-headroom underpasses below the railway, are directly affected by this scenario and actions are to be taken.

It can be seen in the results (Figure 7) that raised sea level will enter the two watercourses, that pass through the central area (Storåna og Stangelandsåna) together with the surface water and foul water sewerage networks. 
There are many coastal towns and cities around the world that have developed and been in existence a long time in this situation. In these places, the flood risk is managed through a mix of measures such as:

- Barriers along (or close to) the coastline.

- Sluice gates on watercourses to avoid sea penetrating inland.

- Low-lying areas where water can be stored during periods of high tide.

- Pumping stations to ensure that flows in watercourses and engineered drainage systems can be discharged to sea.

- Securing all new buildings through defining a minimum ground floor level (the current policy for Sandnes).

- Improving resilience in older buildings and making it easier for them to be brought back into use following flooding incidents.

- Establishing regulations for cellars and their uses.

The future works within this research will put the effort on dealing with the uncertainties that affect the sea level rise data material. Another additional work may be to consider the flood risk due to extreme rainfall events in conjunction with a storm surge.

\subsection{Landslide susceptibility}

The contribution of this research work in terms of landslides, is a new susceptibility map for the current conditions. The findings suggest that the higher susceptibility corresponds to areas with high slope angle given in a clayey soil. The map is in accordance with the historical events and clay pits, however, additional areas area also regarded as susceptible. On the contrary, other relatively flat areas, show a reduced susceptibility at this working scale. We also note that changes in the topography can lead to landslides, as the susceptibility is sensitive to the slope angle.

Ground and surface water are not considered in the study. However, they are considered a significant factor, especially during rainfall events. Natural drainage paths and manmade drainage systems are to be accounted in the future work of this research.

This is a preliminary phase of this research and several questions area still open:

- How to deal with soil composition uncertainty?

- How to assess landslide proneness due to uncertain loads/environmental impacts?

- How to address major vulnerabilities due to instability of soils associated with critical infrastructures and human activities in urban planning?

- What is the most suitable working scale for the purpose of the study.

\section{ACKNOWLEDGEMENTS}

This research is co-funded by the Norwegian Research Council (NFR) and the municipality of Sandnes. We are grateful to the Municipality of Sandnes for their openness and provision of data, in particular to Torbjørn Corneliussen and Graham Fairhust for fruitful conversations and knowledge sharing.

\section{REFERENCES}

Coe, J.A., and Godt, J.W., 2012. Review of approaches for assessing the impact of climate change on landslide hazards. In: Eberhardt E, Froese C, Turner AK, Leroueil S, editors. Landslides and Engineered Slopes, Protecting Society Through Improved Understanding: Proceedings of the 11th International and 2nd North American Symposium on Landslides and Engineered Slopes, Banff, Canada, 3-8 June. London: Taylor \& Francis Group,(1): 371-377.

Crozier, M.J., 2010. Deciphering the effect of climate change on landslide activity: a review. Geomorphology 124, 260-267. https://10.1016/j.geomorph.2010.04.009

Dhakal, A.S., and Sidle, R.C., 2004. Distributed simulations of landslides for different rainfall conditions. Hydrol. Process. 18 (4): 757-776. https://doi:10.1002/hyp.1365

Dijkstra, T.A., and Dixon, N., 2010. Climate change and slope stability: Challenges and approaches. Q. J. Eng. Geol. Hydrogeol. 43(4): 371-385. https://doi.10.1144/1470-9236/09-036

Furseth A., 2006. Skredulykker i Norge: en historisk dokumentar om de mest alvorlige leirskred, snøskred og fjellskred som har rammet oss de siste 500 år. Tun Forlag, 207 pp.

McInnes, R., Jakeways, J., Fairbank, H., and Mathie, E., 2007. Landslides and Climate Change: Challenges and Solutions, Proceedings of the International Conference on Landslides and Climate Change. Taylor \& Francis, Ventnor.

Ramberg, I.B., Bryhni, I., and Nøttvedt, A., 2006. Landet blir til - Norges geologi. Norsk geologisk forening.

Sidle, R.C., and Ochiai, H., 2006. Landslides: processes, prediction, and land use. Water Resour. Monogr. Ser. 18. AGU, Washington DC.

Simpson, M.J.R., Nilsen, J.E.Ø., Ravndal, O. R., Breili, K., Sande, H., Kierulf, H.P., Steffen, P., Jansen, E. Carson, M., and Vestøl, O. (2015). Sea Level Change for Norway: Past and Present Observations and Projections to 2100. Norwegian Centre for Climate Services report 1/2015, ISSN 2387-3027, Oslo, Norway. 